\title{
Prevention and suppression of organized crime - a condition for security in the Balkan countries
}

\author{
Kiril Mitic, PhD \\ Ministry of Interior of the Republic of Macedonia
}

\begin{abstract}
:
This paper attempts to give overview of the asymmetrical threat - the organized crime, with special emphasis on prevention and its suppression as one of the preconditions for security in the Balkan countries.

In all the Balkan countries, regardless of their state governance or regardless whether they are EU member states or not, without exception the activities of the organized crime are present. This because these countries are on the crossroad East-West and North-South, through which the so called "Balkan road" passes, with its "spokes" through which the whole trade and transport of illegal and illicit goods and people is conducted. Having in mind the fact of the rising demand of illicit consumer goods, with suspicious quality, and the illicit goods, primarily drugs for domestic consumers and consumers from the Western European countries, also the increased number of migration processes for numerous reasons, especially the increased number of migrants from the Middle East in the last year, the Balkan countries will be main transit points also in the future. Moreover, they will also be "consumer - countries" of the goods that are illegally traded, because of the low prices available to the increasingly poor citizens of this region. The new migration trend complicates the security of the Balkan countries because of the great number of members of the so called Islamic state, through the channels controlled by the organized crime groups for migrants smuggling, which pass through the Balkan, shifting from the Middle East to the Western European countries with main goal of carrying out terrorist attacks with numerous civilian casualties.

The state as a social category is a guarantor and a guardian of the community, which performs a series of necessary functions through the application of various regulatory tools. The security as a function is its inherent attribute and its purpose is to protect its citizens and the state values from all forms of endangerment. Thus, this paper gives a brief overview of the impact of organized crime on the safety of the citizens and the countries, and a overview of its negative implications on security and a overview the ways and measures for its prevention and suppression.
\end{abstract}


Prevention as a major form of crime prevention, and thus from organized crime, is necessary to achieve its goals, which are primarily reducing crime and increasing the level of security of the citizens and their property, protection of values and occurrences that countries consider of vital meaning, increasing of the ability and capacity of the subjects responsible for crime prevention, as well as development of narrow cooperation between governmental and non governmental institutions responsible for crime prevention. All countries from the Balkan region must establish a degree of values for a zero crime tolerance, not only by declaration, and the strong interstate and regional cooperation to represent one of the key instruments for successful combating of organized crime.

The successful prevention of the organized crime presupposes taking on a series of measures and activities by the countries arising from the National security strategies.

According to this, the strategic interest of the Republic of Macedonia should be strengthening of the capacities to combat organized crime at national and regional level.

Key words: Balkan, organized crime, security, prevention, national strategy

\section{Introduction}

Security is one of the phenomena of the civil society in all its developmental phases. Whether it comes to security of the individual, the states, or more state, or the international community in general, it always comes to the intention to ensure the values and conditions that are considered vital. The main objective of each national policy is the survival of the state and its society, and the requirement for that survival depends on its security. Thus, the goal for an action of all state institutions should be directed toward achieving and maintaining its security. This represents security policy frame, which should provide conditions for achieving internal and external security of the state.

The security of each state is based on the elements of its national power. This encompasses the economical power of the state, the geo-strategic position, natural resources, the dependence on the international market, technical - technological capacities, the national character of the state, the efficiency of the current government to operationalize its decisions, the educational level of the population, reproductive capacity of the population, the moral values, as well as the size of the internal reserves.

The security of the state, as a referent object, but also as a subject of the international community, and its vital interests can be threatened by many external and internal factors driven by different motives. The countries define their vital values and interests as priorities towards which all security activities for their protection are directed. These vital values are determined by the character of the socio - economic relations, by the developmental level of the production forces, by the relationship between the social classes and the legal and political upgrade. Special attention is devoted to their protection, development and protection, because with their survival, 


\section{Seccurity}

the countries realize their own survival and development. Contrary, every endangerment of those values, individual or group, means endangerment of the state, its stability and sovereignty. ${ }^{72}$

The political developments in the Balkan countries imposed the need for creating new security policy as a precondition for establishment of stability in this region. The question for creation of security policy is of an essence because it is part of the process of transition of some of these countries and an indicator of the direction, the pace and scope of reforms.

Organized crime is not the only problem of the Balkan countries, it is a large problem which can be an obstacle for stabilization, maintaining of security and development of the countries in this whole region. It represents non-military, so called non-traditional or soft security threat for the countries and whole regions, which differs from traditional security threats, war or other armed conflicts. Organized crime endangers the fundamental values of contemporary state and negates all principles of its democratic and legal order, it destabilizes the governments, undermines parlametarisam, destroys citizens confidence in state institutions, negates the legislative and social moral, and by that makes the country's citizens feel unsafe. The largest social threat from organized crime comes from its characteristics, high degree of organization of its members, the great thirst for money and power and its international character. Its last characteristic is one of the main reasons why contemporary countries repudiate the dogma for national identity and accept the necessity of international cooperation and establishment of international protection institutions for mutual response which means military, police and judiciary cooperation between countries. It represents serious threat for the national security. However, it is clear that it represent a threat for the political stability, for their social and economic development, and negatively influences their foreign policy. On national level, organized crime endangers the internal stability of the countries through the influence over its key political subjects, which because of their inability to recognize and to effectively oppose the activities and the carriers of organized crime, also because of their active participation in certain criminal activities, are motivated by the desire for profiting. At international level organized crime endangers rules, standards and institutions over which the international system is established and functions. The countries that are in transition phase, countries weakened by political, ethnical and religious clashes, as the Balkan countries, became countries where organized crime easily penetrated and controlled certain territory rather than the state in whose jurisdiction it is. These weak countries with governments with no capacity, credibility, without necessary tools and methods to combat organized crime, represent countries with dysfunctional political and economic relations, with parallel economy and with citizens that have habits of working outside the law or legal framework.

Organized crime's intention is not to tear down the current state system, but to embed in it, in all its pores, that will question the system of political decision making. The central blow from organized crime is suffered by the economy, finances and the bank institutions, because it creates parallel so called grey economy next to the legal one, preventing the developmental strategies of the countries. It abuses the benefits of globalization expressed through the global financial

${ }^{72}$ Стајић Љ. Гилановић Ч. (1994) “Основи безбедности”, Полициска академија у Београду, Београд 


\section{Security}

and commercial system, the modern types of transport and communication, the information technological achievements, the flow of information, services, people and goods, in order to carry out illicit activities by legalizing the criminally obtained profit. The activities of organized crime today are more complex, more sophisticated, market oriented and adjusted to local and global circumstances.

The security function of each state has two forms of intervention: preventive form, in situations where a state with its existence and on time action represents an instrument for deterring from all types of threats and repressive form, by removing the causes of threat and eliminating their holders through the use of force on legally permissible way. ${ }^{73}$

Prevention as a basic form of crime prevention is a set of measures, activities and actors who by mutual action work on realization of the objectives in this area. It is needed in order to achieve the objectives, which are reflected through crime reduction and increasing the level of security of the citizens and their property, increasing the ability of entities in charge of crime prevention and the development of close cooperation between governmental and non-governmental institutions responsible for crime prevention.

\section{Status of organized crime - case study Macedonia}

One of the conditions that foretold the emergence and development of organized crime in the Balkan region, and consequently in Macedonia as its integral part, was the process of privatization. Namely, in 1991 in the Republic of Macedonia there was lack of fresh and clean capital that the structures of organized crime successfully used for investing of their capital mainly in cash. Great part of the members of the old ruling structure so called "red bourgeoisie", in the named period infiltrated the newly created state institutions, and managed to keep their high and key management positions in the new government. A consequence to this was that part of the old business elite in conjunction with the newly elected democratic government managed to keep the privileges that they enjoyed in the economy, by blocking the new social flows more or less. Shortly, the inherited economic and non - economic stare infrastructure moved into the hands of the so called newly created social elite, which at the same time inherited the unstable and unproductive economy, the lack of foreign investments and the great degree of unemployment, a picture that unfortunately has not been changed even today.

Another reason that contributed to the occurrence and the fast development of organized crime was that after 1991 Macedonia was completely deserted and cut from all of its traditional trade partners from the former Yugoslav countries. The war in Croatia and Bosnia and Herzegovina closed the markets for Macedonian products, and in 1992 the UN imposed sanctions on Serbia, which was one of the largest trade partners of Macedonia.

The third reason was that in 1994 Greece, due to the familiar name dispute with Macedonia, officially imposed unilateral embargo, although it actually functioned from 1992, which prevented the access to the port of Thessaloniki, which was vital for the Macedonian economy. This

73 Kotovchevski M. - (2011) "National security", Faculty of Philosophy, Skopje 
imposed situation for Macedonia in that period produced a lost from around 60 million dollars a month. Faced with these problems, Macedonia had to look for new markets and trade roads and transport. Bulgaria on the east and Albania on the west were alternative trade roads and transport for Macedonian products. However, the poor road infrastructure on the East - West corridor and the increased length of the road caused increase of the total costs by $400 \%$ per route. Due to these reasons many businesses collapsed, many factories and companies had to reduce or stop production and close down their manufacturing facilities and many workers lost their jobs. This resulted in the creation of very bad socio-economic situation in the state, the unemployment rose, the population impoverished, foreign investment was lacking, which in turn led to the emergence and development of the so called "gray economy" and "the black market". From the stated above, than and today, for a great part of the population in Macedonia, illegal trafficking represents "legitimate" way for earning and dealing with the bad economic and social state.

Because Macedonia geographically takes the central place of the route of the so called "Balkan route", it represents state whose territory is used for transit and conducting of activities of all known types of illegal traffic. The high level of unemployment and poverty contributed for the structures of organized crime, domestic and international, to recruit young unemployed people for carrying out part of the criminal activities.

The visa liberalization by the European Union for the Macedonian citizens provided for large number of young people to seek livelihood and escape from poverty in the Western European countries. This way, part of them became easy prey for poachers from the criminal structures, mostly with ethnic character, for carrying out illegal activities especially in the area of illegal drug trafficking, stolen motor vehicles trafficking, illegal consumer goods trafficking, especially branded apparel and footwear, as well as intermediation for prostitution.

The negligence in operation and the illegal acquisition of property through corruption was, and due to influence and violence still is one of the most exploited ways of action of the structures of organized crime in the Republic of Macedonia. Organized crime in Macedonia is in close conjunction with the businesses in order to implement their activities of non-transparent and somewhere criminal privatization, criminalization of the public procurement procedures, public tenders, illegal financing of political parties, money laundering, tax evasion, corruption of public officials with high ranks etc. The corruption as a system and a method of operation of the structures of organized crime is priority during illegal activity realization, on account of violence as a method which was characteristic for the beginnings of the phenomenon of organized crime. In several conducted researches for corruption in the Republic of Macedonia, it was proven that the conscience of the population for its existence and destructive effect is on a very high level ${ }^{74}$.

\footnotetext{
74 Despite its practicing by the members of the business structure that corrupt the officials in the public administration in order to meet their requests and needs, it is practiced by common citizens in order to get competent and secure services in short period of time, which became a normal way of proceedings. Certain criminal structures in order to cover the crime, the perpetrators either delay the court procedures until obsolesce, corrupt members from the security structures and the judiciary. The corruption in the Republic of Macedonia influences the deterring of direct foreign investments necessary for economic growth of the state, reviving the industry and creating new jobs.
} 
In Macedonia the structures of organized crime conduct its activities throughout the several of its appearing forms ${ }^{75}$ :

a) "Money laundering". The methods used by the criminal structures for committing this crime are: abuse of non-resident bank accounts, abuse of the system for remittance, abuse of the system for fast money transfer, trading with real estate and stocks, dealing with companies with registered office in the "off-shore" countries, abuse of the export - import operations, setting-up company with one employee so called "one-man-company", for placing or covering up of physical transfer of cash over the borders etc.

b) Violent crime. Violent crimes, especially armed robberies, in the Republic of Macedonia are committed by the structures of organized crime using firearms, within its territory and on its borders. Most common objects of attack are: post offices, postal transport of money, banks, exchange offices, gas stations, and apartments etc., where despite firearms excessive force is used.

c) Illegal trafficking.

1. Illegal drug trafficking. It represents the most common form of organized crime and is in constant raise, where the cooperation between the organized crime groups can be detected. ${ }^{76}$ Certain scientific analysis of this type of organized crime shows that it is very profitable $e^{77}$ and escalates each day by increasing the degree of social and state endangerment. The social endangerment of this type can be perceived through the negative implications in the economic, social, individual or national security, as well as in the politics.

2. Trafficking in human beings. Republic of Macedonia as relatively peaceful territory, in the beginning of the collapse of Yugoslavia that caused wars in these countries, was suitable destination to exodus from all former Yugoslav republics. Firstly, it experienced the Bosnian, and later the Kosovo exodus, where large amount of refugees arrived, among which large number of women and children, later victims of human trafficking. Namely, in that period a number of humanitarian and non-governmental organizations appeared and operated, and in their background hidden were the criminal structures, which used the open and unsecured borders for carrying out their criminal activities of illegal human trafficking. "The inside trade" is characterized by recruiting young women and girls mostly from the rural areas and cities from the east part of Macedonia, to "work" in catering facilities and night clubs in the western part of the country. Here we will mention the phenomenon "mail order bride", an illegal trafficking in young women and girls from Macedonia in the western European countries, by obtaining consent from deceived parents, believing that there their children will actually conclude the marriage. Mostly this phenomenon is present among the members of the Roma ethnic community.

3. Smuggling of migrants. Favorable geostrategic position of the Republic Macedonia also enabled rapid development of migrant smuggling. The migrants are mostly with origin from the countries in the Middle and Far East, that transiting through Macedonia, move to the western

\footnotetext{
${ }^{75}$ Mitikj K. (2013) "Organized crime - non - military threat to Southeast Europe", Skopje

76 Шикман М. (2011) “Организовани криминалитет”, "БИНА”, Бања Лука

77 The estimation for annual income on global level from illegal trafficking in narcotic drugs is between 300 to 500 billion American dollars.
} 
European countries. This is especially expressed in the last year and a half with the beginning of the so called migrant crisis.

4. Illicit trafficking in cultural heritage. The Republic of Macedonia for centuries had a significant cultural and historical heritage, which has been a characteristic of having a strong and healthy culture and civilization in this region with a special symbol of the peoples who lived and worked on this territory. Because of all this, the country's cultural heritage was of interest for appropriation by individuals and countries who illegally tried to approach it. With respect to this organizational form of organized crime, Kotovchevski talks about the practice of some of our neighbors, who without exception have a dismissive attitude towards our history, culture and tradition, towards our roots, identity and existence. Through continuous plundering of our cultural heritage they attempted to destroy all historical and cultural material evidence for our existence. ${ }^{78}$ This way, part of the history and the reality for the existence of the Macedonian people throughout history is outflowing.

d) Environmental crime. The activities of environmental crimes in Macedonia are recognized through the unplanned and uncontrolled logging by the population, because of the high prices of other fuels they use for heating, through the uncontrolled and unprofessional collecting medicinal herbs, by performing illegal excavation of sand from river beds and in their vicinity, through illegal collection of minerals, illegal exports of native, rare and protected animals etc. The structures of organized crime engaged the population, for small wages, to carry out these illicit activities, sometimes unaware that it represents a criminal act.

e) Cyber crime. As one of the modern forms of organized crime in the Republic Macedonia mostly is manifested through hacker intrusions into computer systems, computer fraud as well as abuses of credit and other payment cards.

However, the structures of organized crime in the Republic Macedonia could not achieve their goals without support, or in cooperation with high-ranking public administration officials, mostly employed in the security and financial structures, courts, prosecutor offices, prominent businessmen and influential politicians

For more effective prevention of organized crime an effective harmonization of national legislation with the EU legislation is required, which is a strategic interest for the country. This interest coincides with the clear commitment of the European Union that were expressed at the London Conference (2002) and the Thessaloniki Summit (2003), supported with specific programs for implementation ${ }^{79}$.

\footnotetext{
78 Kotovchevski M. - (2011) "National security", Faculty of Philosophy, Skopje

79 United Nations Convention against transnational organized crime, together with the protocols relating to human trafficking and the fight against smuggling of migrants (2000), the Convention on money laundering, search, seizure and confiscation of criminal funds (2000), the Rome Statute of the International Criminal Court (2002). UN Convention on Illicit Traffic in Narcotic Drugs and Psychotropic Substances (1993), the European Convention on the Transfer of Sentenced Persons (1999), the European Convention on Mutual Assistance in Criminal Matters (1999), the European Convention on Extradition (1999) Penitentiary law Convention on corruption (1999) and Civil law Convention on corruption of the Council of Europe (2002).
} 
So far, there were significant amendments in some laws and new agencies were established for combating organized crime. With the latest amendments to the Criminal Procedure Code and the Criminal Code of the Republic of Macedonia, the penal policy was strengthened regarding the perpetrators of criminal acts of organized crime, and new provisions and incriminations were introduced in order to ease the discovery and proving of these crimes. However, the most important thing is the abiding and without any retention enforcement of these laws.

\section{Similarities and differences in the actions of organized crime in the Balkan countries.}

Characteristically for the countries with fragile democracy and the transition countries, where changes in the political and economic systems occurred, which were or are still are part of the Balkan countries, is the existence of a legal vacuum. The political elites in harness with the economic one deliberately kept this legal vacuum in order to create so called "business oligarchy" for concentration of capital in a small circle of people. The creation and maintenance of this unhealthy climate in the so called transition countries in the Balkans several important factors were of favor. Firstly, the non existence of independent state institutions, which will be under social, not party control, whose job is to prevent, detect and adjudicate the perpetrators of crimes in the area of organized crime. The second factor is recognized through the unfinished and the lack of legal framework, the lack of legal definition of the crimes within the area of organized crime and the improperly constructed criminal procedure. The lack of legally formulated and regulated national strategy for hindering the activities of organized crime and the vast discretionary powers of the state institution officers creates real preconditions for occurrence and development of corruption. The corruption endangers their economic, political and social bases, and at the same time allowes economic power to the members of organized crime. The lack of transparency, or favoritism of certain subjects in the processes of privatization, public procurement, lack of transparency in financing of political parties, nepotism, existence of bureaucratic brakes during issuing different licenses for import or export of raw materials or final products etc., represented a factor for creation of unhealthy social climate in the Balkan countries.

The great influence of the political parties over the public official within the security structures through degradation in service, layoffs of the "unfit" or the opponents of the current political elite and filling up the vacancies with unqualified, unfit party members, justifying it as making the necessary reforms of the security structures, is one of the most significant factors that organized crime gains from. The low income of these public officials, their lack of protection from the arbitrariness of the political or criminal authorities, directed towards one another in part of these countries, their weak material and technical equipment as well as the low level of education for the methods and ways of recognition, prevention and suppression of the forms of organized crime, represents yet another factor that contributes to the survival and continuous operation of organized crime. Namely, in a situation like this where chaos, lawfulness, erosion of moral rules, and where there is lack of system of values in part of the countries in the region, the structures of organized crime see their chance of success. 


\section{Security}

The geostrategic position of the newly formed countries from the dissolution of Yugoslavia and the change in their constitutional order, as well as the change in the constitutional order in Albania, Bulgaria and Romania, and the transition from socialistic into pluralistic democracy, created similar interests and strategy or operation of the criminal structures, not excluding organized crime structures from Greece, as the oldest democratic state on the Balkans. The criminal structures in this region slowly build and strengthen themselves, starting as small partners of already built and strong internationally organized criminal structures, becoming respectable members of the crime world in regional and world measures. With the new social constellations and the development of the information technology, more and more criminal structures conduct their illegal activities by using new information technology in order to establish faster and more secure flow of goods and money, also for creating conditions for bigger self protection.

Characteristic for the criminal structures in the region is that for successful realization of their activities they engaged in close cooperation regardless of their ethnic background, despite the current politics in their countries.

The social danger in these countries from sociological and moral aspect is manifested when after a successfully conducting the activities of money laundering gained with illegal activities, the members of the criminal structures or individuals which by close cooperation and earnings obtained great wealth, is the fact that they managed to "launder" their own biographies. These criminals, now being sole or dominant owners of once great and successful companies or sport clubs, became significant "sponsors" of cultural, sport and other type of manifestations and became a part of the "social elite" deeply established within the government. Especialy dangerous is that these structures are influential in the politics thanks to the funds invested in some of the political parties or in influential persons in the countries. Because smaller part of the countries still haven't precisely defined organized crime and each of them differently titles the daily political needs, also the fact that their security structures do not have the necessary capacity for detection, prevention and suppression of its activities, they must consistently implement the harmonized legislation, to take on measures for improvement and creation of genuine interstate and regional cooperation, and to join the newly formed international organizations and associations, in order to undertake measures and activities on global plan for suppression of the international organized crime.

\section{Prevention and suppression of organized crime, a condition for stability and security in the Balkan countries}

The new security structure in the Balkans is constituted on basis of the modified nature of the threats over the security, were primary threats are the non-military threats, organized crime in the first place. In the years after the Cold war, years of instability, organized crime slowly but surely progressed and developed with ambition to deeply embed in the high governmental structures. Since then, its criminal structures became richer, more influential and more capable to stand the blows coming from the security structures manifested in occasional arrests and seizures of goods subject to illegal trafficking. 
In the 90s of the last century in the Balkan countries the number of security structures members lead by material motives in the first place were included in the processes of criminal privatization and other beneficial criminal activities. By this, the notion of civil rights and liberties coming from the belonging to a certain social and political community were seriously threatened. This threat represents the main source of insecurity in the region that determines the way of thinking and political behavior of citizen for an extended period. This way of political behavior naturally and systematically will influence the future election results and the processes through which the state institutions are established and maintained in the Balkan countries. It can very easily happen for the fear to become dominant social motive for political behavior, and societies controlled by fear can progress very hard and cannot secure a climate of stability and security necessary for their citizens to have authentic, healthy and uncorrupt government.

Prevention as basic form of preventing crime, and by that organized crime, for years was subject to a review of large number of scientists of almost all scientific areas. It is a set of measures, activities, actors, who by acting together work towards realization of the established goals. The goals needed to be realizes are lowering of crime rate and increasing the degree of security for the citizens and their property, increasing the ability and capacities of the subjects in charge of crime prevention, as well as development of narrow cooperation between the governmental and nongovernmental institutions in prevention.

Prevention is implemented through three levels: primary level, secondary and tertiary. On a primary level the prevention is carried out through the education and information system, through the institutions for social protection or through the nongovernmental sector. The secondary level is characterized through carrying out specific programs directed towards the occurrence, the individuals and groups. The tertiary level of prevention aims at prevention of recidivism in situations where crime already exists, and towards serious crimes. According to that, prevention is directed towards the situation or environment, towards social surroundings, towards potential perpetrators, possible victims, as well as towards building of cooperation with the citizens in order for better reaction when crime occurs. ${ }^{80}$

The protection from organized crime contains carrying out several types of measures for prevention, control over the public officials in the first place, eradicating corruption, and raising awareness for the necessity of inclusion of all state institutions, media, and the complete public and relevant political stakeholders in its combating.

Biggest attention should be paid to the uncompromising seizure of property and other property gain that are acquired with the illegal activities of organized crime. Property gain is commonly expressed in profits through property and money and is one of the main targets of organized crime, and therefore its "Achilles heel." If there is lack of that gain, or it is seized from the criminals, organized crime will not exist. ${ }^{81}$

\footnotetext{
80 Република Србија, Министарство унутрашњих послова (2009) “Полазни оквир Националне стратегије превенције криминала" Београд

${ }^{81}$ Crubać M. (2009) "Organizovani kriminal u Srbiji", Zbornik radova Pravnog fakulteta u Splitu, god.46,4/2009
} 


\section{Security}

The criminal intelligence in the last period has been very successful method in prevention from organized crime activities. For that purpose, the countries from the region, in order to successfully suppress organized crime created specialized agencies, whose main activity is collecting criminal intelligence information. They do not act in response to already committed crime, but follow the trends and actions of the structures of organized crime, collect useful information for these criminal structures and strive to predict the possible directions for development of the threats over the security of the countries and citizen, coming from the activities of organized crime.

\section{Strategy for suppression of organized crime in the Republic of Macedonia}

Why the Republic of Macedonia has many partial strategies and not one national strategy for suppression of organized crime? The answer is simple: because the Republic of Macedonia still has not prepared "National strategy for suppression of organized crime" as a main document in which the commitment, goals, directions, ways and institutions in charge of implementation of the activities of the state in prevention, recognition and suppression of this negative phenomenon will be specified.

Namely, this strategy should include the possible trends in development of organized crime, and the possibilities of Macedonia to develop the national capacities and potentials for efficiency in suppressing organized crime. To accomplish the aligned in the strategy, the need of establishment national consensus of all relevant state stakeholders is required, in order to determine the directions for recognition, prevention and repression of organized crime. The delivery and implementation of "The National Strategy for suppression of organized crime" should represent priority for the Republic of Macedonia, among other things, because it represents important step in the process of integration in the European Union and the NATO structures. This strategy should represent a main document that must be in strong conceptual and functional relation with the already delivered strategies in Macedonia, as: Strategy for integral border management ${ }^{82}$, Strategy for suppression of money laundering and financing of terrorism ${ }^{83}$, Strategy for suppression of traf-

\footnotetext{
82 http://www.igu.gov.mk/.../nacionalna/nacionalna_strategija

${ }^{83}$ http://www.usppft.gov.mk/.../..
}

This advisory body is responsible for following and coordinating the activities of the institutions in charge of implementation of this strategy in order for achieving the set goals, improvement of the functioning of the system and proposing of activities for increasing of its efficiency. This body is responsible for successful realization of this strategy, as well as for control over several segments of the system and the system in whole. The realization of the set measures and activities will secure directions or creation of national policy for cooperation and coordination against money laundering and financing of terrorism. Members of this advisory body are representatives from the Ministry of interior, Ministry of justice, the Public prosecutor office, the Customs Administration office, the Public revenue office, the financial police, the National bank of the Republic of Macedonia, the Commission for securities and exchange, the Notary chamber and the Attorney chamber. The members of this advisory body and their substitutes are appointed by the Government of the Republic of Macedonia, and the director of the Public revenue office is the head of this body. 
ficking in human beings and illegal migration ${ }^{84}$, as well as the Strategy for drug handling ${ }^{85}$. This strategy must include several measures and activities that include cooperation of the countries from the region in suppression of the activities of organized crime. "The National Strategy for suppression of organized crime" would represent a public document, which will be regularly updated according to the conducted activities determined with the strategy measures. For successful management and coordinated implementation of the activities determined in the strategy, for making analysis of the findings, for delivering conclusions and giving recommendations based on those analyses, there is a need for preparation of action plans and establishment of national committee or commission.

\section{Conclusion}

In order for successful suppression of organized crime what is needed is professionalization, not partisanship of the employees in the institutions in charge of prevention and suppression of organized crime, which was the case the last several years, their material and technical equipping, electronic connection and building of sole data bases of the security institutions, as well as development of the criminal intelligence and risk analysis, which are important elements in that direction.

By strengthening the measures for suppression of organized crime special accent should be put on strengthening the institutional support, especially of the special units for this purpose. Namely, the security structures by themselves or separated from other state systems, the citizens and society, cannot effectively oppose crime.

The strategic interest of the Republic of Macedonia is the strengthening of state capacities for prevention and suppression of organized crime on national and regional level. The reforms in the judiciary, the close cooperation with the local self-government, with the civil sector, the private sector and the media, are also part of the priority tasks. Strengthening of international cooperation at all levels, as well as conducting joint police operations on regional level are of great importance. By implementing all these elements Macedonia should give great contribution in recognizing, prevention and suppression of organized crime, and contribution in improvement of the national, regional and international security.

\footnotetext{
${ }^{84}$ The Decision is published in the Official Gazette of RM no. 19/2001, 26/2002

The National Commission monitors and analyses the state with trafficking in human beings and illegal migration and coordinates the activities of the institutions, international and nongovernmental organizations involved in problem solving in this area. The Secretariat is a body that works within the National Commission, and the secretary implements the decision of the Commissions and represents this body, composed of members from the international nongovernmental organizations and experts from governmental institutions. Within the National commission, a subgroup against trafficking in children is established.
}

${ }^{85}$ Ministry of health - (2007) "National drug strategy of the Republic of Macedonia" (2006-2012), Skopje 


\section{Security}

Almost all strategies of the Balkan countries are with same goals, same measures, directions and guidance, because the activities of organized crime in the region are manifested through similar or identical forms of appearance, the criminals work by identical methodology, on a small space with the same goal, that being profit and power. These strategies help the development and implementation of the policies for strengthening of the institutional capacities against organized crime on national, regional and international level.

The Republic of Macedonia still has not prepared "National strategy against organized crime", as a main document where the endowments, goals, directions, ways and institutions that are in charge of implementing the activities of the state in a manner of prevention, recognition and suppression of this negative phenomena. This strategy should envisage the possible trends and directions of development of organized crime, and hence the possibilities for Macedonia to develop national capacities and potentials for efficiency in prevention from organized crime. In order to achieve what is outlined in this strategy, the need to establish national consensus of all relevant stakeholders in the country is required, aimed at determining the directions for recognition, prevention and repression of organized crime. The delivery and implementation of "The $\mathrm{Na}$ tional Strategy for prevention of organized crime" should represent a priority for the Republic of Macedonia, among other reasons that it is an important step in the process of integration in the European Union and NATO.

If the development of organized crime is not immediately prevented by using all means available to the Balkan courtiers, organized crime physically will eliminate its opponents and the opponents within the political and governmental structures, will elect and appoint head figures on cultural, health, educational and sport institutions, as well as at the top of the clergy and other religious associations. All Balkan countries, in the future, should establish system of values in which there will be zero tolerance of crime, while the strong interstate and regional cooperation will represent one of the key instruments for successful prevention of organized crime.

\section{Bibliography}

1. Стајић Љ. Гилановић Ч. (1994) “Основи безбедности”, Полициска академија у Београду, Београд

2. Mitikj K. (2013) "Organized crime- non-military threat for Southeast Europe", Skopje

3.Шикман М. (2011) "Организовани криминалитет", "БИНА", Бања Лука

4. Kotovchevski M. (2011) "National security", Faculty of Philosophy, Skopje

5. Grubać M. (2009) "Organizovani kriminal u Srbiji", Zbornik radova Pravnog fakulteta u Splitu, god.46,4/2009 
6. Република Србија, Министарство унутрашњих послова (2009) "Полазни оквир Националне стратегије превенције криминала" Београд

7. Ministry of health (2007) "National drug strategy of the Republic of Macedonia" (2006-2012), Skopje

8. http://www. nisat.org/publications/armsfixers/Chapter8.html

9. http://www. aimpress.ch/dyn/pubs/archive/data/199712/71227-007-pubs-sko.htm

10. http://www.dokkvpp.mvr.bg/NR/../0/anticorrup.pdf

11. http://www.secicenter.org/doc/Strategy_organised_crime_20051.doc

12. http://www.igu.gov.mk/.../nacionalna/nacionalna_strategija

13. http://www.usppft.gov.mk/.../ 